\title{
Nematodes of Elasmobranch Fishes from the Southern Coast of Brazil
}

\author{
Marcelo Knoff $/{ }^{++}$, Sérgio Carmona de São Clemente/*/++, \\ Roberto Magalhães Pinto/ ${ }^{++}$, Delir Corrêa Gomes $/{ }^{+}{ }^{++}$
}

Laboratório de Helmintos Parasitos de Vertebrados, Departamento de Helmintologia, Instituto Oswaldo Cruz, Av. Brasil 4365, 21045-900 Rio de Janeiro, RJ, Brasil *Faculdade de Veterinária, Universidade Federal Fluminense, Niterói, RJ, Brasil

New records for nematode species recovered from elasmobranch fishes in Brazil are established and new systematical arrangements proposed. Parascarophis sphyrnae Campana-Rouget, 1955 from the spiral valve of Sphyrna zygaena is referred for the first time in South America as a new host record. Procamallanus (S.) pereirai Annereaux, 1946, from the spiral valve of Raja castelnaui is reported parasitizing an elasmobranch host. Nematode larvae of the genera Anisakis, Contracaecum, Pseudoterranova and Raphidascaris are listed from the stomach and spiral valves of several hosts. Anisakidae larvae previously referred in Brazil in the genus Phocanema should be reallocated in Pseudoterranova. Nematodes of the genera Anisakis, Contracaecum, Pseudoterranova and Raphidascaris are reported for the first time parasitizing elasmobranchs in Brazil.

Key words: Nematoda - new records - elasmobranch fishes - Brazil

The present investigation adds new data to the study of helminth parasites of elasmobranch fishes from Brazilian marine waters. In Brazil, the only reports on parasites of these hosts are related to the cestodes of the orders Tetraphyllidea and Trypanorhyncha (Rego et al. 1974, Rego 1977, São Clemente \& Gomes 1989a,b, 1992, São Clemente et al. 1991) and to the anisakid nematodes, represented by two species: Terranova trichiuri Chandler, 1935 and T. rochalimai (Pereira, 1935) Johnston and Mawson, 1945 (Vicente et al. 1985, Vicente \& Pinto 1999).

\section{MATERIALS AND METHODS}

In November 1984, June 1985 and July 1986, 217 elasmobranch fishes: 6 Notorynchus pectorosus (Garman, 1884) (90-130 cm of total lenght-tl), 14 Squalus megalops (Macllay, 1881)

Financial support: CNPq Proc. no. 571491/97-9

The authors dedicate this paper in honor of the Oswaldo Cruz Institute, on the occasion of the centenary of its foundation, May 25th 1900.

${ }^{+}$Corresponding author. Fax: +55-21-598.4363. E-mail: dcgomes@gene.dbbm.fiocruz.br

${ }^{++}$CNPq research fellows, Proc. no. 143277/97-9, 302459/88-0, 300374/80-1 and 303124/89-0, respectively.

Received 25 May 2000

Accepted 10 August 2000
(45-59 cm tl), 37 Mustelus canis (Mitchill, 1815) (70.5-113 cm tl), 35 M. schmitti Springer, 1939 (56-98 cm tl), 37 Galeorhinus vitaminicus Buen, 1950 (86-146 cm tl), 7 Carcharhinus brachyurus (Günther, 1870) (80-108 cm tl), 16 Sphyrna zygaena (Linnaeus, 1758) $(81-147 \mathrm{~cm} \mathrm{tl}), 5 \mathrm{~S}$. lewini (Linnaeus, 1758) (75-165 cm tl), 20 Squatina guggenheim (Marini, 1936) (64-87 cm tl), 20 Squatina sp. (81-125 cm tl), 12 Raja castelnaui Ribeiro, 1907 (70-103 cm tl), 1 Dasyatis say (Lesseur,1817) $(58 \mathrm{~cm} \mathrm{tl})$ and 1 D. centroura (Mitchill, 1815) $(103 \mathrm{~cm} \mathrm{tl})$ were captured in the coast of the State of Rio Grande do Sul ( $30^{\circ} 40^{\prime}$ 'S$33^{\circ} 40^{\prime} \mathrm{S}$ and $50^{\circ} 40^{\prime} \mathrm{W}-53^{\circ} 20^{\prime} \mathrm{W}$; $12-100 \mathrm{~m}$ depth), by professional fishermen of the oceanographic ship Atlântico Sul. In March 1998, 46 elasmobranch fishes: 1 Hexanchus griseus (Bonnaterre, 1788) (132 cm tl), 7 Heptranchias perlo (Bonnaterre, 1788) (87-107.4 cm tl), 16 Squalus sp. (41-67 cm tl), 9 Scyliorhinus haeckeli (Ribeiro, 1907) (41.5-54.5 cm tl), 5 Carcharhinus signatus (Poey, 1868) (120-150 cm tl) and 8 Dipturus trachyderma (Krefft and Stehmann, 1975) (133.5$176 \mathrm{~cm} \mathrm{tl}$ ) were captured about 125 miles off the littoral of State of Paraná (25 $50^{\circ} \mathrm{S}-25^{\circ} 52^{\prime} \mathrm{S}$ and $45^{\circ} 23^{\prime} \mathrm{W}-45^{\circ} 25^{\prime} \mathrm{W}$; 200-500 $\mathrm{m}$ depth), by professional fishermen of the fishing boat Icanhema VI. Parasites were collected, fixed, stained and mounted following Amato et al. (1991). The classification of the nematode parasites considered herein is that of Yamaguti (1961), Chabaud (1975 a, b), Hartwich (1974), Anderson (1992). The prevalence, intensity and mean intensity of infec- 
tion are indicated in accordance to Bush et al. (1997). The drawings were made with a camera lucida connected to an Olympus BH-2 microscope. All measurements are in millimeters; ranges of measurements are followed by mean values (when indicated) within parentheses. Voucher specimens were deposited in the Coleção Helmintológica do Instituto Oswaldo Cruz (CHIOC), Fiocruz, Rio de Janeiro, RJ, Brazil. Deposited anisakidid larvae refer to one sample from each host species. Host specimens collected between 1984 and 1986 were determined on board by Dr Carolus Maria Vooren and were not deposited. Host specimens collected in 1998 and 1999 were determined by Drs Alberto Ferreira Amorim and Carlos Arfelli and at least one specimen of each species of these fishes was deposited as voucher host in the Coleção Ictiológica do Instituto de Pesca, Santos, SP, Brazil: D. trachyderma no. IP1961; C. signatus no. IP1962; H. perlo no. IP1963; H. griseus no. IP1964; Squalus sp. no. IP1965; S. haeckeli no. IP 1966.

\section{RESULTS}

Spiruroidea

Cystidicolidae Skrjabin, 1945

Parascarophis sphyrnae Campana-Rouget, 1955

(Figs 1-3)

Description of specimen (based on one female). Female: body 30.0 long, maximum width 0.144 . Head with a cap-like cuticular expansion which extends backwards rather dorsally than ventrally, dorsal face 0.050 long and ventral face 0.020 long. Buccal capsule 0.220 long. Esophagus 4.0 long without a clear distinction between muscular and glandular portions. Nerve ring 0.216 from anterior extremity. Vulva at the mid anterior portion of the body, 19.7 from anterior extremity. Ovijector directed upwards and then turning downwards, near its connection with the opposed uterus. Eggs thin-shelled, embryonated, 0.025-0.029 long by 0.011-0.014 wide, without polar filaments. Anus 0.160 from posterior extremity. Excretory pore not observed.

Host: Sphyrna zygaena (Sphyrnidae)

Site of infection: spiral valve

Locality: littoral of the State of Rio Grande do Sul, Brazil

Prevalence $(\mathrm{P})=6.2 \%$

Intensity of infection $(\mathrm{I})=1$

Number of specimens recovered: 1 female

Specimen deposited: CHIOC No. 34263 (voucher) - whole mount.

Camallanoidea

Camallanidae Railliet \& Henry, 1915

Procamallanus (S.) pereirai Annereaux, 1946

(Figs 4-7)
Description of specimens (based on one male and five females). Male: body 10.67 long, maximum width near midlength 0.158 . Buccal capsule 0.090 long by 0.061 wide, 14 spiral bands. Esophagus 1.09 long, muscular anterior portion of esophagus 0.489 long and glandular posterior portion 0.604 long. Nerve ring 0.226 from anterior extremity. Caudal alae wide, continuous anteriorly with symetrical pair of pedunculated papillae; precloacal pairs three, postcloacal six pairs. Spicules unequal and similar. Longer spicule 0.420 and shorter spicule 0.220 long. Cloaca 0.144 from posterior extremity. Tail possessing two small spines. Female: body 13.3 - 17.8 long, maximum width at its middle, 0.273-0.360. Buccal capsule $0.100-0.108$ long by $0.086-0.090$ wide, with 14 spiral bands. Muscular anterior portion of esophagus 0.518 0.576 long and glandular posterior portion 0.763 0.864 long. Nerve ring $0.237-0.316$ from anterior extremity. Vulva 6.99 from anterior extremity. Ovijector long directed downwards. Rectum 0.108 - 0.144 long. Anus $0.140-0.180$ from posterior extremity. Tail with two spines.

Host: Raja castelnaui (Rajidae)

Site of infection: spiral valve

Locality: coast of the State of Rio Grande do Sul, Brazil

Prevalence $(\mathrm{P})=25 \%$

Mean intensity of infection $(\mathrm{MI})=2$

Number of specimens recovered: 1 male, 5 females Specimens deposited: CHIOC No. 34264, 34265a, b, c and 34266 (vouchers) - whole mounts.

Ascaridoidea

Anisakidae Skrjabin \& Karokhin,1945

Data on the number of specimens of Anisakidae nematode larvae (infrapopulation) in elasmobranch hosts collected between 1984 and 1986 (State of Rio Grande do Sul) and 1998 (State of Paraná) in the Southern Brazil and their number of deposit in the CHIOC are presented in Table I. Prevalence, intensity or mean intensity of infection in elasmobranch hosts are on the Tables II and III for those necropsies performed in 1984-1986 and 1998, respectively. Fishes collected in March 1999 from State of Santa Catarina were negative to Anisakidae nematode larvae.

$$
\begin{gathered}
\text { Anisakinae Railliet \& Henry, } 1912 \\
\text { Anisakis Dujardin, } 1845 \\
\text { Anisakis sp. }
\end{gathered}
$$

Hosts: Hexanchus griseus (Hexanchidae); Heptranchias perlo (Heptranchidae); Squalus megalops (Squalidae); Mustelus canis (Triakidae); Galeorhinus vitaminicus (Triakidae); Carcharhinus signatus (Carcharhinidae); Dipturus trachyderma (Rajidae); Squatina sp. (Squatinidae). 
Contracaecum Railiet \& Henry, 1912 Contracaecum sp.

Hosts: Hexanchus griseus (Hexanchidae); Heptranchias perlo (Heptranchidae); Scyliorhinus haeckeli (Scyliorhynidae); Mustelus canis (Triakidae); Mustelus schmitti (Triakidae); Galeorhinus vitaminicus (Triakidae); Carcharhinus brachyurus (Carcharhinidae); Carcharhinus
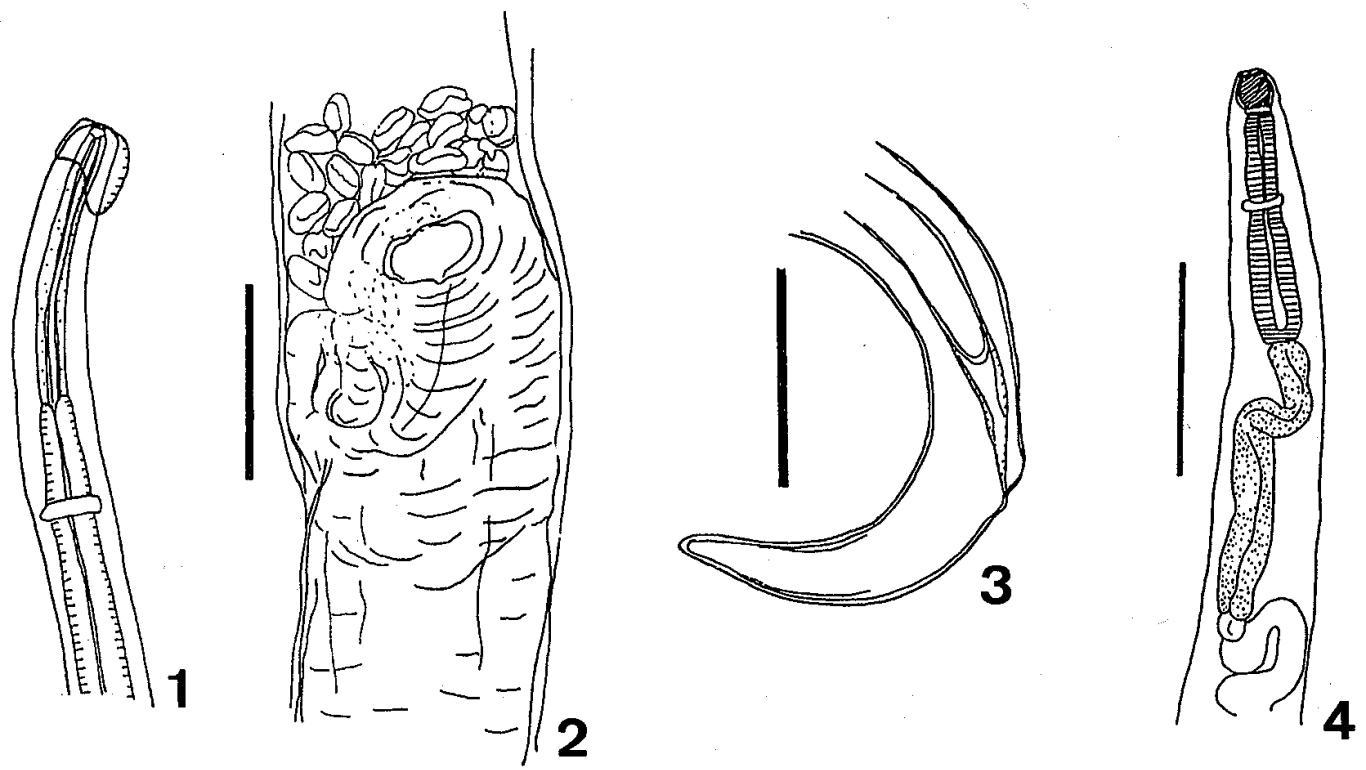
(Sphyrnidae); Dipturus trachyderma (Rajidae); Squatina sp. (Squatinidae).

Pseudoterranova Mosgovoy, 1950 Pseudoterranova sp.

Hosts: Squalus megalops (Squalidae); Mustelus canis (Triakidae); Mustelus schmitti (Triakidae); Galeorhinus vitaminicus (Triakidae).
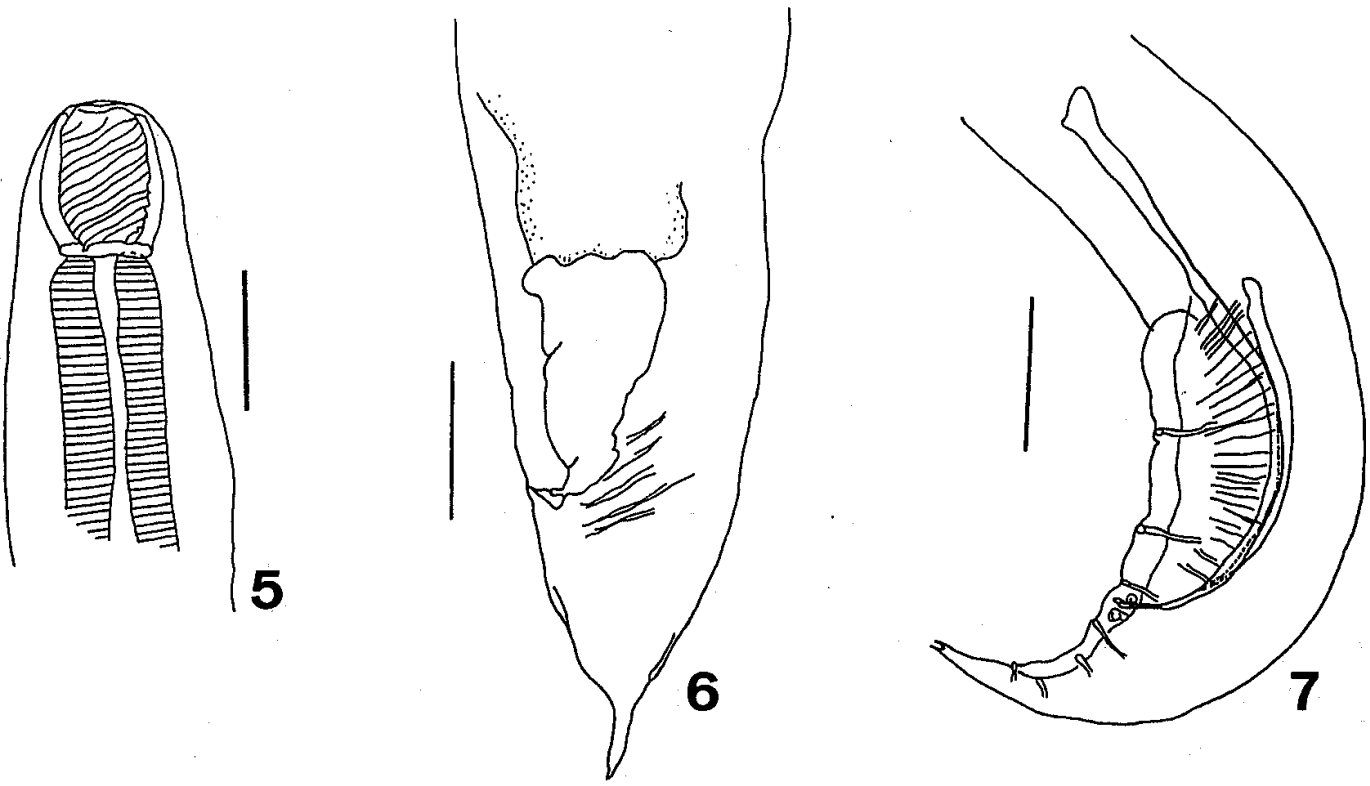

Parascarophis sphyrnae. Fig. 1: anterior region of female, lateral view. Fig. 2: vulvar region, ventral view. Fig. 3: posterior end of female, lateral view (bars of Figs 1-3 =0.1 mm). Procamallanus $(S$.) pereirai. Fig. 4: anterior region of female, lateral view $($ bar $=0.5 \mathrm{~mm})$. Fig. 5: buccal capsule of female, lateral view. Fig. 6: posterior region of female, lateral view. Fig. 7: posterior region of male, lateral view (bars of Figs $5-7=0.1 \mathrm{~mm}$ ). 


\section{TABLE I}

Number of the specimens (infrapopulation) of the anisakid nematode larvae burden in each positive elasmobranch host collected between 1984 and 1998 in the states of Rio Grande do Sul and Paraná and Coleção Helmintológica do Instituto Oswaldo Cruz (CHIOC) deposit number

\begin{tabular}{|c|c|c|c|c|c|}
\hline Hosts & Host sex & Larvae spp. & $\begin{array}{c}\text { No. of } \\
\text { specimens }\end{array}$ & Site of infection & $\begin{array}{l}\text { Vouchers } \\
\text { CHIOC no. }\end{array}$ \\
\hline \multirow[t]{3}{*}{ Hexanchus griseus } & \multirow[t]{3}{*}{ Female } & Anisakis & 10 & Spiral valve & 33880 \\
\hline & & Anisakis & 5 & Stomach & - \\
\hline & & Contracaecum & 3 & Stomach & 33881 \\
\hline Heptranchias perlo & Female & Contracaecum & 1 & Stomach & - \\
\hline H. perlo & Female & Contracaecum & 2 & Spiral valve & 33882 \\
\hline H. perlo & Female & Anisakis & 1 & Spiral valve & 33883 \\
\hline Squalus megalops & Female & Pseudoterranova & 2 & Stomach & 34276 \\
\hline S. megalops & Female & Pseudoterranova & 7 & Stomach & - \\
\hline S. megalops & Female & Anisakis & 1 & Spiral valve & 33878 \\
\hline Scyliorhinus haeckeli & Male & Contracaecum & 1 & Stomach & - \\
\hline S. haeckeli & Male & Contracaecum & 1 & Spiral valve & 33884 \\
\hline S. haeckeli & Female & Raphidascaris & 1 & Spiral valve & 33885 \\
\hline \multirow[t]{2}{*}{ Mustelus canis } & \multirow[t]{2}{*}{ Female } & Anisakis & 1 & Spiral valve & 34271 \\
\hline & & Pseudoterranova & 1 & Spiral valve & 34273 \\
\hline M. canis & Female & Pseudoterranova & 1 & Spiral valve & - \\
\hline M. canis & Female & Pseudoterranova & 3 & Spiral valve & - \\
\hline M. canis & Female & Anisakis & 1 & Spiral valve & - \\
\hline M. canis & Female & Contracaecum & 22 & Stomach & 34272 \\
\hline M. canis & Female & Pseudoterranova & 2 & Spiral valve & - \\
\hline M. schmitti & Female & Contracaecum & 4 & Spiral valve & 34274 \\
\hline M. schmitti & Female & Contracaecum & 5 & Spiral valve & - \\
\hline M. schmitti & Male & Pseudoterranova & 6 & Spiral valve & 34275 \\
\hline Galeorhinus vitaminicus & Male & Anisakis & 6 & Spiral valve & 34267 \\
\hline G. vitaminicus & Male & Contracaecum & 9 & Spiral valve & 34268 \\
\hline G. vitaminicus & Male & Anisakis & 3 & Spiral valve & - \\
\hline G. vitaminicus & Male & Anisakis & 3 & Spiral valve & - \\
\hline G. vitaminicus & Female & Pseudoterranova & 13 & Spiral valve & 34269 \\
\hline \multirow[t]{2}{*}{ G. vitaminicus } & \multirow[t]{2}{*}{ Female } & Contracaecum & 10 & Spiral valve & - \\
\hline & & Raphidascaris & 6 & Spiral valve & 34270 \\
\hline G. vitaminicus & Female & Pseudoterranova & 4 & Spiral valve & - \\
\hline Carcharhinus brachyurus & Female & Contracaecum & 1 & Spiral valve & 34278 \\
\hline Carcharhinus signatus & Male & Anisakis & 1 & Stomach & - \\
\hline \multirow[t]{2}{*}{ C. signatus } & \multirow[t]{2}{*}{ Male } & Anisakis & 2 & Spiral valve & 33886 \\
\hline & & Contracaecum & 2 & Spiral valve & \\
\hline \multirow[t]{3}{*}{ C. signatus } & \multirow[t]{3}{*}{ Female } & Anisakis & 1 & Stomach & - \\
\hline & & Contracaecum & 7 & Stomach & 33887 \\
\hline & & Contracaecum & 1 & Spiral valve & - \\
\hline \multirow[t]{2}{*}{ Sphyrna zygaena } & \multirow[t]{2}{*}{ Female } & Contracaecum & 9 & Stomach & 33879 \\
\hline & & Contracaecum & 1 & Spiral valve & - \\
\hline S. zygaena & Male & Contracaecum & 2 & Spiral valve & - \\
\hline Squatina sp. & Male & Anisakis & 1 & Spiral valve & 34279 \\
\hline Raja castelnaui & Female & Raphidascaris & 2 & Spiral valve & - \\
\hline$R$. castelnaui & Female & Raphidascaris & 1 & Spiral valve & 34277 \\
\hline R. castelnaui & Male & Raphidascaris & 4 & Spiral valve & - \\
\hline Dipturus trachyderma & Male & Contracaecum & 5 & Stomach & - \\
\hline D. trachyderma & Male & Contracaecum & 4 & Stomach & 33889 \\
\hline D. trachyderma & Male & Anisakis & 1 & Spiral valve & 33888 \\
\hline D. trachyderma & Female & Contracaecum & 1 & Spiral valve & - \\
\hline \multirow[t]{2}{*}{ D. trachyderma } & Male & Contracaecum & 1 & Spiral valve & - \\
\hline & & Raphidascaris & 1 & Spiral valve & 33890 \\
\hline \multirow[t]{2}{*}{ D. trachyderma } & Male & Anisakis & 1 & Spiral valve & - \\
\hline & & Contracaecum & 2 & Spiral valve & - \\
\hline
\end{tabular}


TABLE II

Prevalence (P) and intensity (I) or mean intensity (MI ${ }^{a}$ of the anisakid nematode larvae burden in elasmobranch hosts collected between 1984 and 1986 (State of Rio Grande do Sul)

\begin{tabular}{llcc}
\hline Larvae spp. & Hosts & $\mathrm{P}(\%)$ & $\mathrm{I}^{\text {or MI }}$ \\
\hline Anisakis & Squalus megalops & 7.1 & 1 \\
& Mustelus canis & 5.4 & $1^{a}$ \\
& Galeorhinus vitaminicus & 8.1 & $4^{a}$ \\
Contracaecum & Squatina sp. & 3.8 & 1 \\
& M. canis & 2.7 & 22 \\
& M. schmitti & 5.7 & $4.5^{a}$ \\
& G. vitaminicus & 5.4 & $9.5^{a}$ \\
& Carcharhinus brachiurus & 2.5 & 1 \\
Pseudoterranova & Sphyrna zygaena & 12.5 & $6^{a}$ \\
& S. megalops & 14.3 & $4.5^{a}$ \\
& M. canis & 10.8 & $1.7^{a}$ \\
Rhaphidascaris & M. schmitti & 2.9 & 6 \\
& G. vitaminicus & 5.4 & $8.5^{a}$ \\
& G. vitaminicus & 2.7 & 6 \\
& Raja castelnaui & 25 & $2.3^{a}$ \\
\hline
\end{tabular}

TABLE III

Prevalence (P) and intensity (I) or mean intensity (MI ${ }^{a}$ of the anisakid nematode larvae burden in elasmobranch hosts collected in 1998 (State of Paraná)

\begin{tabular}{llcc}
\hline Larvae spp. & Hosts & $\mathrm{P}(\%)$ & $\mathrm{I}^{\text {or MI }}{ }^{a}$ \\
\hline Anisakis & Hexanchus griseus & 100 & 15 \\
& Heptranchias perlo & 14.3 & 1 \\
& Carcharhinus signatus & 60 & $1.3^{a}$ \\
Contracaecum & Dipturus trachyderma & 25 & $1^{a}$ \\
& H.griseus & 100 & 3 \\
& H. perlo & 28.6 & $1.5^{a}$ \\
& Scyliorhinus haeckeli & 22.2 & $1^{a}$ \\
& C. signatus & 40 & $5^{a}$ \\
Rhaphidascaris & D. trachyderma & 62.5 & 1 \\
& S. haeckeli & 11.1 & 1 \\
\hline
\end{tabular}

Raphidascarinae Hartwich,1954

Raphidascaridinea Chabaud, 1965

Rhaphidascaris Railiet \& Henry, 1915

Rhaphidascaris sp.

Hosts: Scyliorhinus haeckeli (Scyliorhynidae); Galeorhinus vitaminicus (Triakidae); Raja castelnaui (Rajidae); Dipturus trachyderma (Rajidae).

\section{REMARKS}

Description of $P$. sphyrnae was based on female specimens parasitizing the spiral valve of $S$. diplana from the coast of Senegal (CampanaRouget 1955a, b). Our specimen from the spiral valve of S. zygaena is 2.5 times longer than those from Senegal, but in accordance to established morphological parameters for the species. This is the first report of $P$. sphyrnae in South America and in the new host species. Procamallanus (S.) pereirai has been reported from a variety of hosts and different geographical localities (Annereaux 1946, Sogandares-Bernal 1955, Noble \& King 1960, Hutton 1964, Joy 1971, 1974, Yin 1983, Sood 1989, Frost \& Dailey 1994). In Brazil this nematode was referred parasitizing Paralonchurus brasiliensis (Pinto et al. 1984, Vicente et al. 1985). Larval stages of $P$. (S.) pereirai have been reported in Brazil for the teleosts Stellifer brasiliensis, Nebris microps, Porichthys porosissimus, Symphurus tesselatus and Menticirrus americanus (Santos et al.1999). Procamallanus (S.) pereirai is here referred for the first time from an elasmobranch host. The Anisakidae larvae reported herein represent the genera Anisakis, Contracaecum, Pseudoterranova and Raphidascaris. Considering the lifecycle of these nematodes (Anderson 1992) it is possible to suppose that the third-stage larvae are ingested with the intermediate fish hosts. Several anisakid species have been referred from freshwa- 
ter and marine fishes in Brazil (Vicente et al. 1985, Barros \& Amato 1993, São Clemente et al. 1994, 1995a, b, 1996, Vicente \& Pinto 1999). According to Gibson (1983), Pseudoterranova must be recognized as the oldest available name for Phocanema and based on this fact, species previously referred to the genus Phocanema should be reallocated in Pseudoterranova. This is the first report of anisakid nematodes of the genera Anisakis, Contracaecum, Pseudoterranova and Raphidascaris parasitizing elasmobranchs in Brazil, considering that only $T$. trichuri Chandler, 1935 and $T$. rochalimai (Pereira, 1935) Johnston and Mawson, 1945 were previously referred from these hosts (Vicente et al. 1985). Thus, the occurrence of the larvae studied herein, represents new records for Brazilian hosts.

\section{ACKNOWLEDGMENTS}

To Dr Carolus Maria Vooren from the Universidade do Rio Grande, State of Rio Grande do Sul, for the identification of fishes captured between the years 19841986, to Drs Alberto Ferreira Amorim and Carlos Arfelli from the Instituto de Pesca, Santos, State of São Paulo, for the identification of fishes captured between the years 1998-1999 and to the fishermen of the research ship Atlântico Sul of the Fundação Universidade do Rio Grande and of the fishing boat Icanhema VI from Santos, both for helping during capture of hosts.

\section{REFERENCES}

Amato JFR, Boeger WA, Amato SB 1991. Protocolos para Laboratório - Coleta e Processamento de Parasitos de Pescado, Imprensa Universitária, Universidade Federal Rural do Rio de Janeiro, Seropédica, Brasil, 81 pp.

Anderson RC 1992. Nematode Parasites of Vertebrates, CAB International, Cambridge University Press, London, $578 \mathrm{pp}$.

Annereaux RF 1946. A new nematode, Procamallanus pereirai, with a key to the genus. Am Microsc Soc 65: 299-303.

Barros GC, Amato JFR 1993. Larvas de anisakídeos de peixe-espada, Trichiurus lepturus L., da costa do Estado do Rio de Janeiro, Brasil. Rev Brasil Biol 53: 241-245.

Bush AO, Lafferty KD, Lotz JM, Shostak AW 1997. Parasitology meets ecology on its own terms: Margolis et al. revisited. J Parasitol 83: 575-583.

Campana-Rouget 1955a. Parasites de poissons de mer ouest-africains récoltés par J. Cadenant. IV. Nématodes (1re Note). Parasites de Sélaciens. Bull l'Inst Franç Afr Noir 14(A3): 818-839.

Campana-Rouget 1955b. Sur deux nouveaux genres de spirurides parasites de poissons; discussion systématique des genres voisins. Ann Parastol 30: 346-362.

Chabaud AG 1975a. CIH Keys to the Nematode Parasites of Vertebrates 3 . Keys to Genera of the Order Spirurida. Ascaridoidea. Part I. Camallanoidea, Dracunculoidea, Gnathostomatoidea, Physalopte- roidea, Rictularoidea and Thelazioidea, Commonwealth Agricultural Bureau, Farnham Royal, UK, $27 \mathrm{pp}$.

Chabaud AG 1975b. CIH Keys to the Nematode Parasites of Vertebrates 3 . Keys to Genera of the Order Spirurida. Ascaridoidea. Part II. Spiruroidea, Habronematoidea and Acuarioidea, Commonwealth Agricultural Bureau, Farnham Royal, UK, 29 pp.

Frost PJ, Dayley MM 1994. Helminth parasites of some southern California fishes with a redescription of Proctoeces magnorus Manter, 1940 (Digenea: Fellodistomidae) and description of Choanodera meseri sp. n. (Digenea: Apocreadidae). Bull South California Acad Sci 93: 110-117.

Gibson DI 1983. The systematics of ascaridoid nematodes - a current assessment. In AR Stone, HM Platt, LF Khalil (eds), Concepts in Nematode Systematics. The Systematics Association Special, Vol 22, Academic Press, New York, USA, p. 321-338.

Hartwich G 1974. CIH Keys to the Nematode Parasites of Vertebrates. Part II. Keys to Genera of the Ascaridoidea, Commonwealth Agricultural Bureau, Farnham Royal, 27 pp.

Hutton RF 1964. A second list of parasites from marine and coastal animals of Florida. Trans Am Microsc Soc 83: 439-447.

Joy JE 1971. Spirocamallanus pereirai (Nematoda: Camallanidae) from the croacker, Micropogonias undulatus, in Texas. J Parasitol 57: 390.

Joy JE 1974. Incidence and intensity of Spirocamallanus pereirai (Nematoda: Camallaidae) infections in the croacker, Micropogon undulatus (Linnaeus) and spot, Leiostomus xanthurus Lacèpéde, from Texas. Contr Mar Sci 18: 1-16.

Noble ER, King RE 1960. The ecology of the fish Gillichthys mirabilis and one of its nematode parasites. J Parasitol 46: 670-685.

Pinto RM, Vicente JJ, Noronha D 1984. First report of Ascarophis Van Beneden, 1871: A. brasiliensis n. sp. (Nematoda, Ascarophidinae) and Procamallanus (Spirocamallanus) pereirai Annereaux, 1946 (Nematoda, Procamallaninae) in South America. Mem Inst Oswaldo Cruz 79: 491-494.

Rego AA 1977. Cestóides parasitas de Carcharinus longimanus (Poey, 1861). Rev Brasil Biol 37: 847852.

Rego AA, Santos JC, Silva PP 1974. Estudos de cestóides de peixes do Brasil. Mem Inst Oswaldo Cruz 72: 187-204.

Santos CP, Cárdenas MQ, Lent H 1999. Studies on Procamallanus (Spirocamallanus) pererai Annereaux, 1946 (Nematoda: Camallanidae), with new host records and new morphological data on the larval stages. Mem Inst Oswaldo Cruz 94: 635-640.

São Clemente SC, Gomes DC 1989a. Dasyrhynchus pacificus Robinson, 1965 (Trypanorhyncha: Dasyrhynchidae) description of the adult form. Mem Inst Oswaldo Cruz 84: 113-116.

São Clemente SC, Gomes DC 1989b. Trypanorhyncha from sharks of southern Brazilian coast: Eutetrarhynchus vooremi sp. n. and two other species parasites of Mustelus (Pisces, Triakidae). Mem 
Inst Oswaldo Cruz 84: 475-481.

São Clemente SC, Gomes DC 1992. Description of the adult form of Nybelinia (Syngenis) rougetcampanae Dollfus, 1960 and some new data on $N$. (N.) bisulcata (Linton, 1889) (Trypanorhyncha: Tentaculariidae). Mem Inst Oswaldo Cruz 87: 251-255.

São Clemente SC, Gomes DC, Serra Freire NM 1991. Prevalência e intensidade de infecção de helmintos da ordem Trypanorhyncha em elasmobrânquios no litoral do Sul do Brasil. Parasitol al Día 15: 9-14.

São Clemente SC, Lima FC, Uchoa CMA 1995a. Parasitos de Balistes vetula L. e sua importância na inspeção do pescado. Rev Bras Cienc Vet 2: 39-41.

São Clemente SC, Marques MC, Serra Freire NM, Lucena FP 1995b. Análise do parasitismo de peixe espada Trichiurus lepturus L. do litoral do Rio de Janeiro-Brasil. Parasitol al Día 19: 146-149.

São Clemente SC, Silva MC, Lucena FP 1996. Sobrevivência de larvas de anisakídeos de peixe espada, Trichiurus lepturus L., submetidos aos processos de salmoragem e cocção. Rev Bras Cienc
Vet 3: 79-80.

São Clemente SC, Uchoa CMA, Serra Freire NM 1994. Larvas de anisakídeos em Pagrus pagrus L. e seu controle através de baixas temperaturas. Rev Bras Cienc Vet 1: 21-24.

Sogandares-Bernal F 1955. Some helminth parasites of fresh and brackish water fishes from Louisiana and Panama. J Parasitol 41: 587-594.

Sood ML 1989. Fish Nematodes from South Asia, Kalyani Publishers, New Deli, 704 pp.

Vicente JJ, Pinto RM 1999. Nematóides do Brasil. Nematóides de peixes. Atualização: 1985-1998. Revta bras Zool 16: 561-610.

Vicente JJ, Rodrigues HO, Gomes DC 1985. Nematóides do Brasil. 1a. Parte: Nematóides de peixes. Atas Soc Biol Rio de Janeiro 25: 1-88.

Yamaguti S 1961. Systema Helminthum. Volume III. Parts I and II. Nematodes, Interscience Publishers, Inc., New York, 1261 pp.

Yin WZ 1983. On some nematodes from marine fishes in Hainan Island, China. Acta Zool Sin 8: 225-228. 